\title{
Explore and Analyze the Right to Education for Disabled People in Higher Inclusive Education
}

\author{
Ye Aihui*, Ma Hui \\ School of Arts and Law, Wuhan University of Technology,China \\ *273315297@qq.com
}

\begin{abstract}
The right to education for college students is an important part of educational right. It is the elementary right of the constitution in equality and legality. It not only has the general features of the right to education, but also is necessarily considered to be independent and free. An endless discriminatory and low quality teaching model can obstruct the free flow of educational resources and may prevent the student from being a useful team player in society. Finally, it may lead to the difficulty of job placement, integration into society and the realization of fundamental life values. Higher confluent education advocates to guarantee of the right to education for disabled people and in addition can promote the development of higher inclusive education.

The objective of higher inclusive education is to help disabled students accessing to education with ordinary students in the same higher institute. This article puts forward the personal view of improving and ensuring the right to education for disabled students based on the basic contents of right to education and the present conditions of higher inclusive education.
\end{abstract}

Key words : Inclusive education, the right to education, legal protection

\section{Introduction to the right to education for disabled college students and inclusive education}

The right to education for disabled college students means disabled college students get the identity to get into the institute of higher learning by law and they enjoy the right to take advantage of using the teaching resources. Educational right in itself is a kind of right that the citizen get and has the right to use rare higher education resources by their talents and disabled people also enjoy the right.

Higher inclusive education is a way for disabled students to access to education with ordinary students in the same higher institute. It lays emphasis on providing common education environment for disabled students rather than a separated environment.

\section{Basic contents of the right to education}

It mainly includes three aspects: the right of access to education, education conditions and educational outcomes.

\subsection{The right of access to education}

Firstly, the right of access to education means educatees have the right to receive education by all means by law. It is a right for students to receive all kinds of study when meeting all standards of enrollment.

\subsection{The right of education conditions}

The right of education conditions means the citizens have the right to receive education and the right to get material assistance.

It mainly consists of two factors: one is that the citizens have the right and chance to receive education, the other is that the nation provides places and facilities to teach and create conditions for citizens to receive education. The guarantee of the right to education is an important prerequisite to finish their studies.

\subsection{The right of educational outcomes}

The finial part is the right to get the educational outcomes. Students get the chance to receive education, 
share and utilize education conditions and then be educated and finally get outcomes. School and related units should give some appraisals to some extent, such as award diploma or graduate successfully and meets the identification of the society. [1]

\section{Present conditions of higher inclusive education in China, present conditions of higher inclusive education overseas and existing problems:}

Existing problems of the right to education for college students in higher inclusive education in China Firstly, China has mistakes over the understanding of the concept. The original understandings include disabled people should receive education in special schools since disabled students may lead to the inconvenience of management and higher costs.

Secondly, it lacks the planning of system management. Although special education is the backbone in China and the system has been formed, it also leads to the implement of special education. [2]

Finally, facts existing which can not be neglected by us that many colleges set barriers to enroll disabled students. [3]

\section{Regard to higher inclusive education and the guarantee}

The improvement measures of higher inclusive education shall be analyzed from the following three aspects. [4]

\subsection{Improving the right of access to education}

The key point of improving access to education is that the local government should lay emphasis on the right to education.

Access to education includes three indexes, namely the right to enroll, the right to further education and the right to select a school. The government should guarantee the right to enroll of disabled students and enable them to access to ordinary education like other ordinary students.

Besides, government should also guarantee the right to further education and prevent some colleges from setting barriers to deprive the right to further education. Besides, it should formulate related laws and regulations and strengthen social supervision. The government should also guarantee the right to select a school and ensure their normal rights. It requires to increase education costs, improve the teaching quality of teachers, optimize teaching resources and enable disabled students to grow up free like other students. It is the common identifications of the society that educational equality should be emphasized especially for disabled students. Calling upon the society to pay attention to disabled students and form a sense of big love and make them feel at home. Although they have physical defects, their right to education and love should not be deprived so that they can create their own values in their common life. [5]

\subsection{Improving the right of education conditions}

The key point of improving the right of education conditions is to guarantee that for disabled students. Educational management should be strengthened, especially the daily management, such as enrollment verification, archives administration, supervision and management. It should be combined flexibly and make overall planning to achieve resource sharing, service optimizing and well-aligned teaching.

The right of education conditions is mainly discussed from the aspects of hardware facilities and software facilities. Hardware facilities mainly include teaching building, dormitory, library and so on; software facilities mainly include class atmosphere, institutional improvement, teachers ability and so on. As for the common people, compulsory education belongs to public service and can be protected by law. As for disabled students, they should also get some support, such as necessary information service, institutional guarantee and basic specification shall be listed into the basic public service of the education for disabled 
students.

\subsection{Improving the right of educational outcomes}

The right of educational outcomes shows the equality of educational outcomes and it is the final objective of inclusive education. After disabled students finishing their study successful, they need to get an equal and fair social development environment and they eager for success and approval.

Firstly, government should make overall plans and take all factors into consideration. It should make all work, decrease the resistance brought by disabled students, increase their self-confidence and ask them to fit in the society and help them improve sense of ownership.

Secondly, it shall be guided by the government, assisted by the society to open some training centers and help disabled students to get some survival skills and decrease the resistance brought to the society.

Finally, the government should formulate some measures to protect the interests of disabled students, give them some preferential policies and encourage them to combine study with society.

\subsection{Improving the judicial remedies system of the right to education in higher inclusive education}

The right to education is a kind of elementary right and can't be deprived at will. It should be protected and restrained by the law. In the inclusive education, it includes the main bodies, such as nation, society, school and students. So, it requires different ways of judicial remedies methods. As for the judicial remedy methods for invading the main body of the right to education, it includes civil action and administrative lawsuit. [6]

\subsubsection{Use civil action to remedy the right to education of disabled students.}

The right to education is not only regulated by the constitution, but also regulated by the education act. As a elementary right, it involves the relations of legal person and organization and it provides possibilities for the civil action for disabled students. During the process of civil action, it also requires for fluent law channel and provide convenience to disabled students.

\subsubsection{Use administrative lawsuit to remedy the right to education of disabled students.}

School plays many roles in the society and the legal person with civil subject also has other identity. School has the right to enroll, reward and punish students and it is a compulsory force to educatees. It is compulsory and volitive unilaterally and it meets the features of administrative power. Hence, we can use administrative lawsuit to protect our rights. If the management of the school seriously influences the educatees or deprive their right to education, then students can resort to administrative lawsuit.

\section{Reference}

[1] Gao Shuzhen. Comments on Right to Education. Jilin University doctoral dissertation, 2007.

[2] De-Lawrence Lamptey,Michelle Villeneuve, Patricia Minnes, Mary Ann McColl. Republic of G hana's Policy on Inclusive Education and Definitions of Disability, Journal of Policy and Practice in Intellectual Disabilities, 2015, Vol.12 (2).

[3] Sun Feng. Case Studies on Disabled College Students Join Higher Inclusive Education, Culture and History Vision (theory), 2013, 10.

[4] Huang Xingguo. Comments on Legal Relation and Legal Protection of the Right to Education of Chinese College Students, Shanxi Normal University learned journal social science edition, 2012, 1.

[5] Mo Jihong. The Connotation of Protecting Right to Education by Constitution ,The Jurist , 2003, 3.

[6] Fan Lvbing. Study on Legal Remedy System of the Right to Education. Southwestern University doctoral dissertation, 2006. 